\title{
Moving postgraduate ophthalmology education online- experiences of a nationalised live video-linked series
}

\author{
Huzaifa Malick ${ }^{1} \cdot$ Simerdip Kaur ${ }^{2} \cdot$ Pratibha Veeramani $^{3} \cdot$ Amy-lee Shirodkar $^{4}$
}

Received: 6 August 2020 / Revised: 15 August 2020 / Accepted: 18 August 2020 / Published online: 28 August 2020

(c) The Author(s), under exclusive licence to The Royal College of Ophthalmologists 2020

\section{To the Editor:}

The postgraduate ophthalmology teaching scene in the UK has witnessed a rapid increase in the range of available online webinars [1]. As an early response to the uncertainty faced by trainees at the start of the COVID-19 pandemic, we organised a series of live video-linked (LVL) lectures with the intention of investigating the feasibility of national, curriculum based, consultant-led webinars accessible to all UK ophthalmology trainees. We assess the efficacy of this educational platform through speaker and participant feedback.

Participant and speaker evaluation of bi-weekly 30-min online webinars via $\mathrm{ZOOM}^{\odot}$ (Zoom Video Communications, Inc) from April to June 2020 (28 April 2020 to 30 June 2020) were obtained through anonymous online surveys posted at the end of each session (Fig. 1). Social media portals and a designated website were also used to circulate event details.

We received a total of 213 responses from participants of every training deanery and level in the UK, including consultants. Eighty-five percent accessed the sessions from home. Ninety-five percent found it easy to interact with the speaker with only fourteen percent experiencing technical issues affecting their learning experience. Ninety-nine percent of participants would attend further LVL sessions, with sixty-six percent feeling this platform could replace traditional face-to-face (F2F) sessions (Fig. 2).

$\triangle$ Huzaifa Malick

h.malick@nhs.net

1 Leicester Royal Infirmary, Leicester, UK

2 Kent and Canterbury Hospital, Kent, UK

3 King's College Hospital, London, UK

4 Moorfields Eye Hospital, London, UK
Feedback from speakers showed that $92 \%$ found interaction with attendees easy. Sixty-nine percent had taught via LVL prior to these sessions. Ninety-two percent felt they would consider teaching via this platform in the future with thirty-nine percent feeling that LVL teaching could entirely replace F2F postgraduate ophthalmology education.

To our knowledge, this is the first series of ophthalmic specialist training curriculum-focused LVL sessions delivered regularly on a national scale in the UK [2]. Feedback from participants and speakers showed a positive trend towards the future use of LVL teaching for ophthalmology. As the sessions gained popularity, a core group of regular participants from across the country became evident, thereby helping to create a virtual community of practice. In 2002, Wenger et al. defined a CoP, summarised by Ranmuthugala et al. as a "shared domain of interest, a community that pursues the shared interest, and practice or shared repertoire of resources". Such CoPs have proven efficacy in healthcare settings, including evidence-based change in clinical practice $[3,4]$.

Inability to visualise the audience was highlighted by speakers as a limitation of the platform, although the negative effect of this could be mitigated partially by asking attendees to keep their video on.

Feedback for the programme showed that this method of collaborative learning was well accepted by both attendees and participants. It is likely that the future lies somewhere in between the old and the new. F2F teaching has stood the test of time and may remain the convention in many departments. However, the added benefits of LVL to share high-quality resources at a national level has huge potential to provide learners with the flexibility of how and when they learn. Future studies of this type of virtual learning should focus on improving speaker and attendee rapport and evaluating the extent of knowledge transmission when compared to traditional learning environments. 
Fig. 1 Feedback Questions Table showing the feedback questions asked to participants vs speakers.

\begin{tabular}{|c|c|}
\hline Questions for participants & Questions for presenter \\
\hline What was the date of the session you attended? & $\begin{array}{l}\text { What was the date of the session you presented } \\
\text { the teaching? }\end{array}$ \\
\hline What is your grade? & $\begin{array}{l}\text { Have you ever delivered a teaching session via } \\
\text { a video conferencing platform before? }\end{array}$ \\
\hline Which deanery are you currently based in? & $\begin{array}{l}\text { Where were you when you delivered the } \\
\text { session? }\end{array}$ \\
\hline $\begin{array}{l}\text { Are you currently working in ophthalmology or } \\
\text { have you been re-deployed to another area? }\end{array}$ & Was the length of the session adequate? \\
\hline $\begin{array}{l}\text { If you have not been able to attend any of the } \\
\text { previous C-19 Eyeducation sessions, can you } \\
\text { please tell us why? }\end{array}$ & $\begin{array}{l}\text { Was it easy to interact with attendees using this } \\
\text { platform? e.g read and answer questions }\end{array}$ \\
\hline $\begin{array}{l}\text { Do you still have weekly local/regional } \\
\text { postgraduate ophthalmology teaching in your } \\
\text { area (eg via Zoom or Microsoft teams)? }\end{array}$ & $\begin{array}{l}\text { Was the clarity of the software adequate (in } \\
\text { terms of microphone quality/transmission } \\
\text { quality)? }\end{array}$ \\
\hline Where were you when attending this session? & $\begin{array}{l}\text { Did you feel that delegates were able to ask you } \\
\text { the questions they wished? }\end{array}$ \\
\hline Was the length of the session adequate? & $\begin{array}{l}\text { During the session, did you feel that the } \\
\text { delegates were finding your talk useful? (in } \\
\text { terms of physical and visual body } \\
\text { language/feedback) }\end{array}$ \\
\hline $\begin{array}{l}\text { Was it easy to ask a question/engage with the } \\
\text { speaker using this platform? }\end{array}$ & $\begin{array}{l}\text { Would you consider teaching virtually via video- } \\
\text { link after the current social distancing laws are } \\
\text { relaxed? }\end{array}$ \\
\hline $\begin{array}{l}\text { Did you experience any technical difficulties that } \\
\text { adversely affected your learning experience? }\end{array}$ & $\begin{array}{l}\text { Do you think this type of virtual video-teaching } \\
\text { could replace conventional face to face } \\
\text { teaching? }\end{array}$ \\
\hline $\begin{array}{l}\text { After your experience during this session, do } \\
\text { you think this type of video conference teaching } \\
\text { could replace traditional face to face teaching? }\end{array}$ & $\begin{array}{l}\text { Do you have anything else you would like to } \\
\text { mention to improve future sessions? }\end{array}$ \\
\hline $\begin{array}{l}\text { Would you attend a future session by C19- } \\
\text { Eyeducation? }\end{array}$ & \\
\hline $\begin{array}{l}\text { Do you have anything else you would like to } \\
\text { mention to either the speaker or the organising } \\
\text { team? }\end{array}$ & \\
\hline
\end{tabular}

After your experience during this session, do you think this type of video conference teaching could replace traditional face to face teaching?

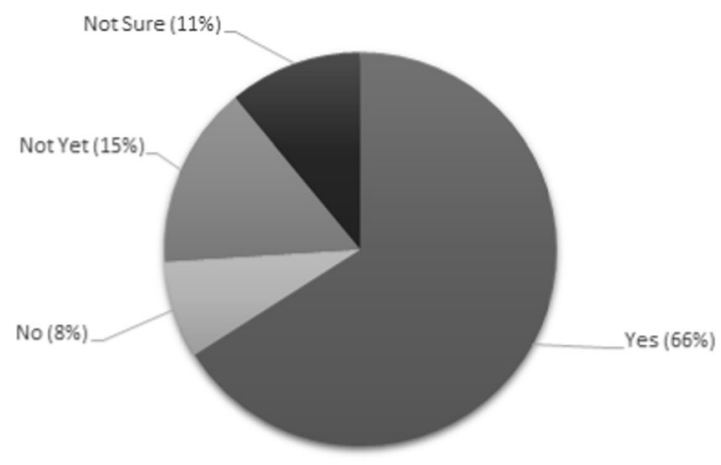

Fig. 2 LVL vs F2F Teaching - Participants' thoughts on the feasibility of LVL teaching replacing F2F teaching entirely.

\section{Compliance with ethical standards}

Conflict of interest The authors declare that they have no conflict of interest.

Publisher's note Springer Nature remains neutral with regard to jurisdictional claims in published maps and institutional affiliations.

\section{References}

1. Hussain R, Singh B, Shah N, Jain S. Impact of COVID-19 on ophthalmic specialist training in the United Kingdom-the trainees' perspective. Eye. 2020;2020:1-4. https://doi.org/10.1038/s41433020-1034-6.

2. Royal College of Ophthalmologists. Ophthalmic specialist curriculum. Royal College of Ophthalmologists. 2018. https://www. rcophth.ac.uk/curriculum/ost/. Accessed Jul 2020.

3. Wenger E, McDermott R, Snyder WM. Cultivating communities of practice. Boston: Harvard Business School Press; 2002. p. 304. 
4. Ranmuthugala G, Plumb JJ, Cunningham FC, Georgiou A, Westbrook JI, Braithwaite J. How and why are communities of practice established in the healthcare sector? A systematic review of the literature. BMC Health Serv Res. 2011;11:273. https://doi.org/10. 1186/1472-6963-11-273. 